\title{
ORGANIZATION OF AVIATION ENTERPRISES' INTERACTION BASED ON THE DIGITAL PLATFORM
}

\author{
Kateryna Molchanova
}

\begin{abstract}
The article considers the approach to digital transformation of the aviation industry in terms of organizing the interaction of supply chain participants involving air transport based on the digital platform. Digital transformation is considered not only as a tool of information interaction, but also as a business model that creates value by uniting consumers and producers of goods and services. There was performed a statistical analysis of indicators characterizing the state of the global aviation market and that of Ukraine in particular, of the global crisis impact caused by the COVID-19 pandemic on air transport and changes in the field of passenger and freight transport; there were analyzed the possible ways of overcoming the consequences of the crisis for airlines and airports and the use of digital technologies in developing anti-crisis strategies. The necessity of forming a united information space in the supply chain to ensure the rapid exchange of information between cooperating transport hubs and government agencies, including the exchange of information on the management of production and commercial activities of transport enterprises was highlighted. The role of air transport in servicing global supply chains was also emphasized, as it offers highly integrated and comprehensive fast delivery with safe, reliable, convenient and highly efficient services. There was proposed a scheme of information interaction among supply chain participants involving air transport based on the digital platform in the context of united information space. The use of the digital platform as a tool for organizing interaction was justified, as this technology provides massive opportunities to achieve increased efficiency not only of individual units, but also of the entire supply chain.
\end{abstract}

Keywords: digitalization, digital transformation, digital platform, interaction of aviation enterprises, organization of interaction

JEL Classification: M31, L86

\section{Author:}

Kateryna Molchanova

National Aviation University, 1 Liubomyra Huzara ave., Kyiv, Ukraine, 03058

E-mail:molchanova@nau.edu.ua

https://orcid.org/0000-0003-1846-2492

Citation: Molchanova, K. (2021). Organization of Aviation Enterprises' Interaction Based on the Digital Platform. Virtual Economics, 4(1), 77-97. https://doi.org/10.34021/ve.2021.04.01(4) 


\section{Introduction}

The main advantage of digital technologies is the formation of personalized offers for the consumer. The latest digital technologies are actively used in the field of air transportation. Technologies of virtual and augmented reality, big data and analytics, the Internet of Things, the use of beacons and sensors, robotics are actively introduced in the work of airlines and airports. It should be noted that most technologies are aimed at passengers. One example of digitalization of the air cargo industry is e-freight technology - an international standard for electronic registration and maintenance of air cargo, developed and recommended by the International Air Transport Association (IATA), which provides electronic document flow among air cargo participants and among participants and state control bodies at air checkpoints along the route of the cargo (Molchanova, 2014, Marintseva, 2013). However, the speed of this technology's global implementation was not as high as predicted by IATA experts. For example, in Ukraine, discussions on introducing one of the e-freight components, namely the electronic Air Waybill (e-AWB), began in 2014, but this has not been implemented yet.

The global crisis in the aviation industry due to the COVID-19 pandemic has highlighted the importance of air cargo transport and stimulated generation of development strategies in this area. Information interaction with the help of digital technologies has become critical under the conditions of quarantine restrictions, isolation and remote work.

The purpose of this study is to substantiate and develop a mechanism for information interaction of participants in supply chains, involving air transport, using digital platforms, which creates preconditions for the emergence of new business models and development of airlines and logistics operators.

The results of the study continue the series of publications in foreign and domestic scientific literature the purpose of which was to consider the general issues of business digitalization, as well as the use of modern information and communication technologies in the production and commercial activities of enterprises.

At the same time, despite the significant number of scientific papers on methods and tools of business digitization, as well as the use of digital technologies in enterprises, the problem of integrated interaction of enterprises in supply chains using digital platforms has been insufficiently studied. The issues of optimizing the information exchange among aviation enterprises in air cargo transport chains to cut operating costs and reduce regional disparities under conditions of global pandemic and a breakdown in air transport activity needs further development.

\section{Literature Review}

The importance and relevance of solutions to the problem of organizing information interaction between the production processes of the airport is reflected in the work by Dalinger (2017). The airport is considered as a system and there is proposed an integrated 
form of organization, the purpose of which is to combine different processes into a single production system. The formation of digital platforms for transport and logistics in order to generate digital services for consumers on the basis of technological integration of various resources and infrastructures is covered in the work by Marusin \& Ablyazov (2019). The research by Dmitriev \& Plastunyak (2019) is interesting from the viewpoint of considering the transport and logistics service development on the basis of integrated digital platforms and the use of digital technologies.

The paper by M. de Reuver et al. (2018) is devoted to the issue of industries' transformation through introducing digital platforms. Researchers deeply analyze the idea of "digital platform" in terms of different concepts and describe the ways in which digital platforms can change the activities of various sectors of the economy. Existing approaches to the classification of digital platforms are analyzed and the author's own classification is developed in the work by Ryzhkova (2019). The paper also describes business schemes and features of creating the working classification of digital platforms.

The main features of multisided digital platforms are studied in the work by Hagiu (2014). The paper describes the network effect of digital platforms and shows that all participants in digital platforms are its full consumers, and they interact directly with each other. The localization of companies based on digital platforms is heterogeneous around the world, as illustrated by a study by Evans \& Gawer (2016). Researchers conducted a global survey of companies and identified those that are digital platforms with a market value of at least $\$ 1$ billion. The study also demonstrates a wide range of industries in which business activity has grown significantly, built on a platform approach.

Researchers Sutherland \& Jarrahi (2018) analyzed the concept of centralized and decentralized platform as an effective organizational principle of the sharing economy and evaluated the attitude of scientists to the technology itself. Scholars have also described the relationship between digital platforms and the sharing economy.

The formation of a digital platform model that provides interaction of autonomous management systems of economic entities - federal, regional, institutional, commercial and other organizational systems, is described in the work by Zatsarinnyy \& Shabanov (2019). The purpose of their study was to solve economic problems in order to consolidate the production resources of economic agents.

The description of a business model of the digital platform was made in the research by Tauscher \& Laudien (2018), who studied a number of markets for developing taxonomies of business models of the market, as well as identified several clearly distinguishable types of business models, which showed the lack of a unified approach to creating value in markets and platforms in particular.

The tendency to increase the number of decentralized platforms due to blockchain technology was analyzed in the research by Chen et al. (2020), who assessed the trade-offs between 
centralization and decentralization and hypothesized semi-decentralization as a more effective governance structure.

\section{Methods}

The choice of research methods is determined by the nature of the actual data on the state and dynamics of global and national markets of air passengers and cargo transport.

The used statistical and comparative analysis allowed revealing global and local market trends, determining the congestion of airports and estimating the potential intensity of cargo flows. 2020 was a year of significant global upheaval for the economy and society. Due to the spread of the COVID-19 virus, the pandemic has closed many borders and locked citizens in their homes. Many sectors of the economy are in crisis and the air transport industry is almost the largest. The terrorist attacks of September 11, 2001, the global financial crisis of 2007-2008 contributed to the fact that the demand for air transportation fell significantly, but the pandemic almost closed the sky.

In early 2020, China's domestic aviation market fell first, but by March it began to recover. Simultaneously with the spread of the disease worldwide, its negative impact on air transport was felt everywhere from February to the end of April, when passenger traffic fell by $94 \%$ compared to the same period last year, and much of the industry was idle. Beginning in May, air traffic began to recover slowly, but very slowly in almost all markets.

Due to restrictions on international travel, flights between cities around the world have almost stopped. Domestic air transportation was performed in small volumes in China and the United States. However, most scheduled intercontinental airlines have been canceled. Air transportation, which continued to be performed during this period, mainly concerned cargo. But it should be noted that about half of air cargo is carried in the holds of passenger airplanes and the almost complete cessation of passenger flights has created a serious problem for global supply chains, which are the basis of the modern economy.

In Figure 1 you can see a map of air routes, which compares April 2019 and 2020.

Although air traffic has been slowly recovering since May 2020, strict border crossing restrictions remained in place until the end of the year, as most countries adhere to strict quarantine restrictions. There is also a threat of mutated coronavirus waves, which could again lead the country which has slowly begun to ease restrictions to strict quarantine. IATA predicts that most aviation jobs will be threatened by the crisis.

The airlines that went bankrupt in 2020 include the following: AtlasGlobal (Turkey), Airltalia (Italy), Flybe (UK), Braathens Regional Airlines (Sweden), NokScoot (Thailand, Singapore), Virgin Australia (Australia), Virgin Australia (South Africa) and others, totaling about 40. 

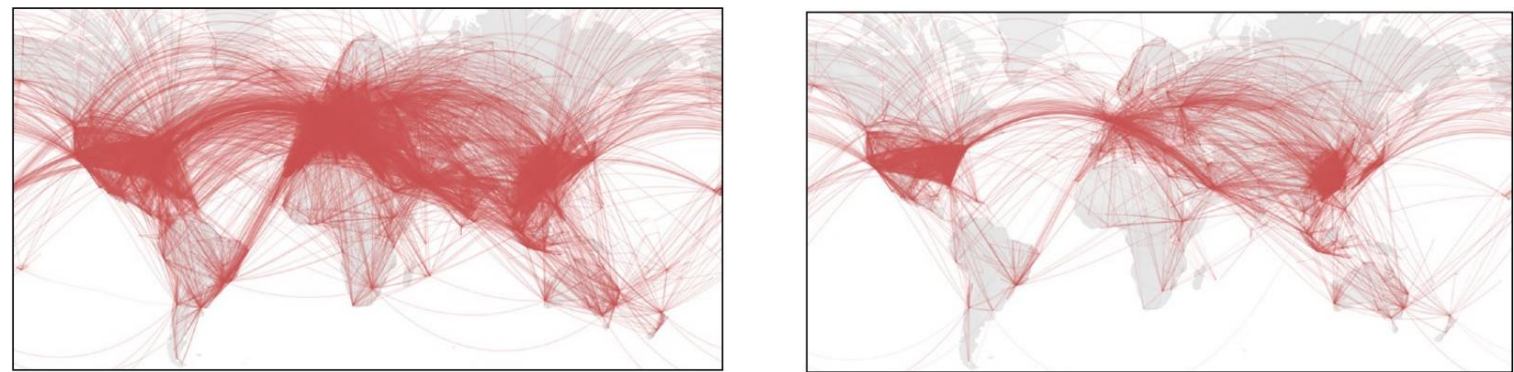

Figure 1. The map of air routes in April 2019 and 2020 and the impact of COVID-19 on air communication

Source: IATA (2020, November 25). Air Connectivity: Measuring connections that drive economic growth.

In total, the aviation industry received revenues of 365 billion USD, which is only $43.6 \%$ of those in 2019 ( 838 billion USD). The number of passengers carried in 2020 accounts for 1.8 billion people, according to IATA (IATA. (2020). Deep Losses Continue Into 2021), and this is $35 \%$ of the figure for 2019 (4.5 billion passengers). Revenues from passenger transportation in 2020 amounted to 191 billion USD, compared to 612 billion USD received in 2019 (31.2\%).

The volume of air cargo has decreased slightly, as it remains important. The history of air transportation in 2020 is different from that before the pandemic. The volume of transported goods decreased, but not as much as the number of passengers. At the peak of air freight in April, the number of ton-kilometers (t-km) decreased by about a quarter (see Figure 2). By September, the volume of air cargo increased by only $8 \%$ compared to the previous year. Cargo, with rare exceptions, is not a COVID-19 carrier. Moreover, it remains important for supporting global supply chains and for transporting medical equipment and pharmaceuticals.

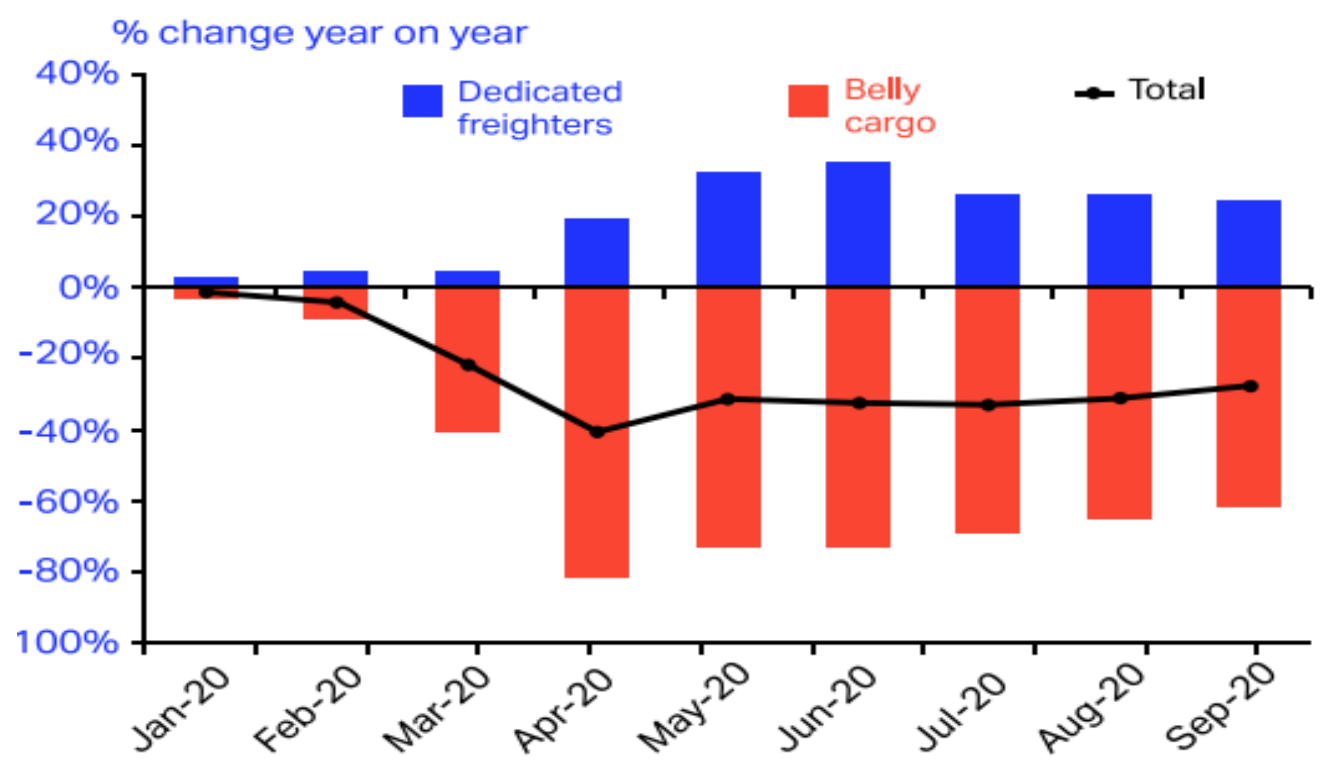

Figure 2. The tendency to change the air cargo transportation during the COVID-19 pandemic, ton-kilometers

Source: IATA (2020, November 25) 
The reliability of air freight in comparison with passenger traffic is different on the main trade routes. The most stable was the market of the North Pacific, where usually $90 \%$ of air traffic is performed by specialized cargo planes. It can be argued that in 2020 this market has not suffered from the cessation of cargo transportation by passenger planes (see Figure 3). The crisis hit the Asian region harder, as most cargo was transported by passenger planes.

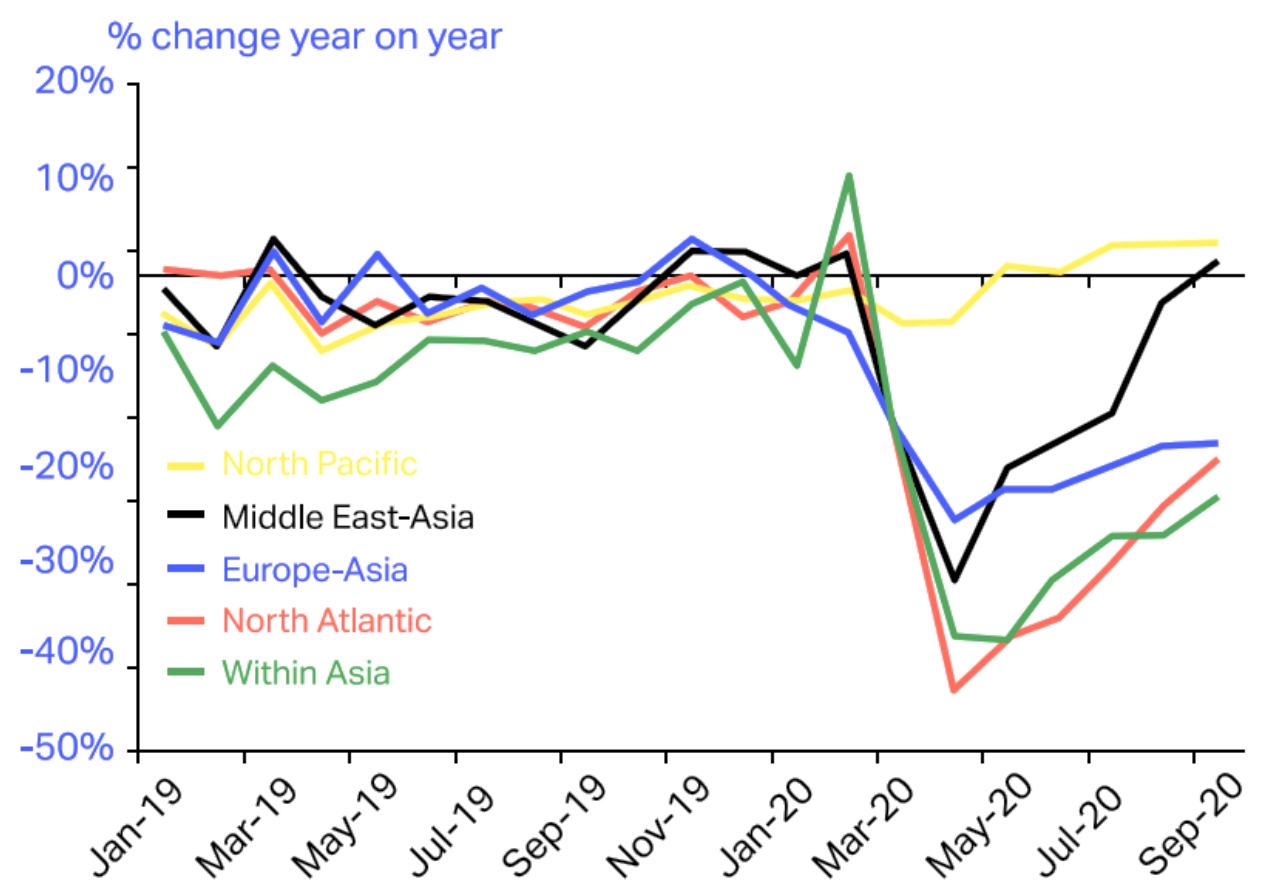

Figure 3. The trend to change air cargo transportation in the main trade areas during the COVID-19 pandemic, ton-kilometers

Source: IATA (2020, November 25)

Demand for air freight from global perishable supply chains, manufacturing and services is supported by a V-shaped recovery, which reflects growing business confidence amid a significant recovery in output as the economy reboots and returns to work. (see Figure 4).

Fast delivery of materials and finished products by air is vital. As of October 2020, business confidence remained above pre-crisis levels, supporting demand for air cargo in countries such as China, the United States and Germany. However, the recent resumption of quarantine in Europe will be devastating, as it indicates a decline in business confidence in France.

The total operating income of the air transport industry in 2020 decreased by more than $60 \%$ (see Figure 5). As numerous costs in the aviation business, including fleet costs and skilled labor, are difficult to estimate, declining revenues have led to unprecedented losses for the industry. According to experts, the loss in 2020 will exceed 118 billion USD after taxes. The most difficult for the industry was the 2 nd quarter of 2020, and in the second half of the year the recovery was very slow. 


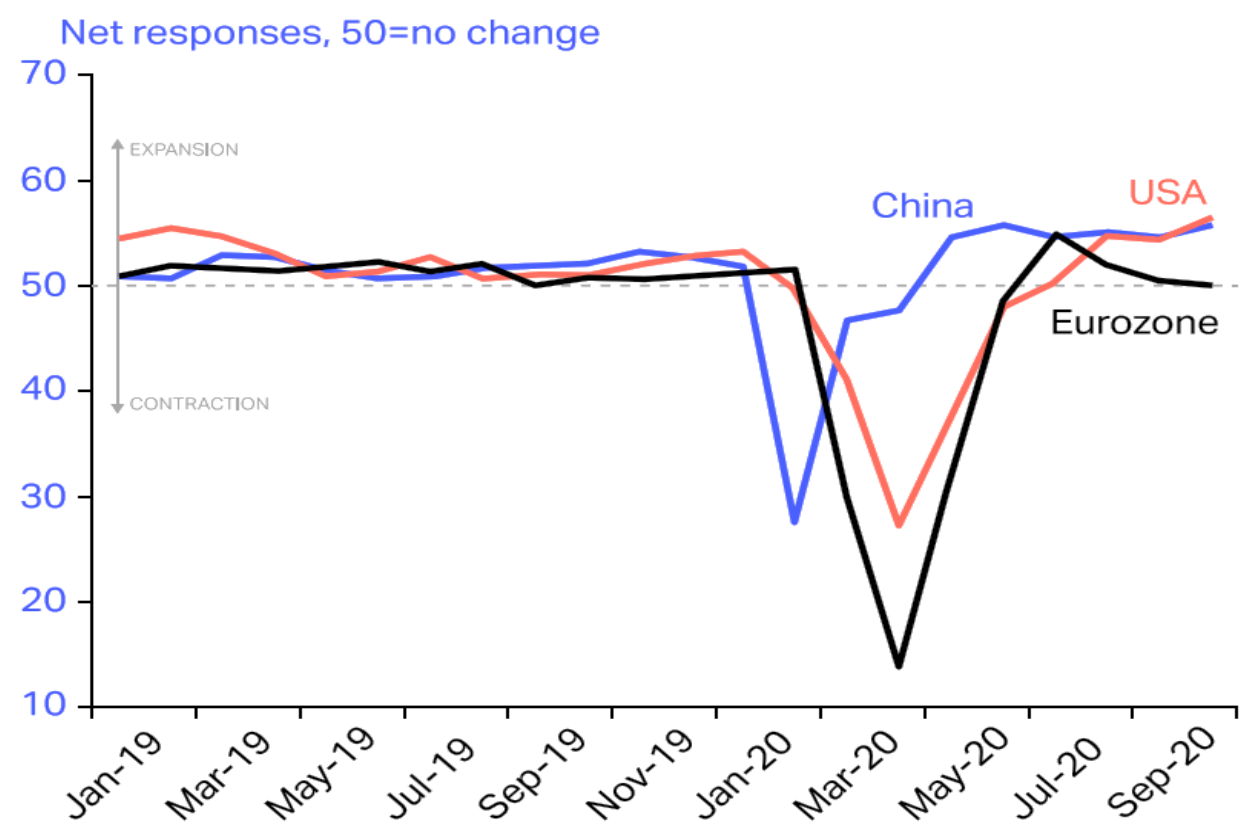

Figure 4. Business confidence in production and services (Procurement Managers Index) during the global COVID-19 pandemic

Source: IATA (2020, November 25)

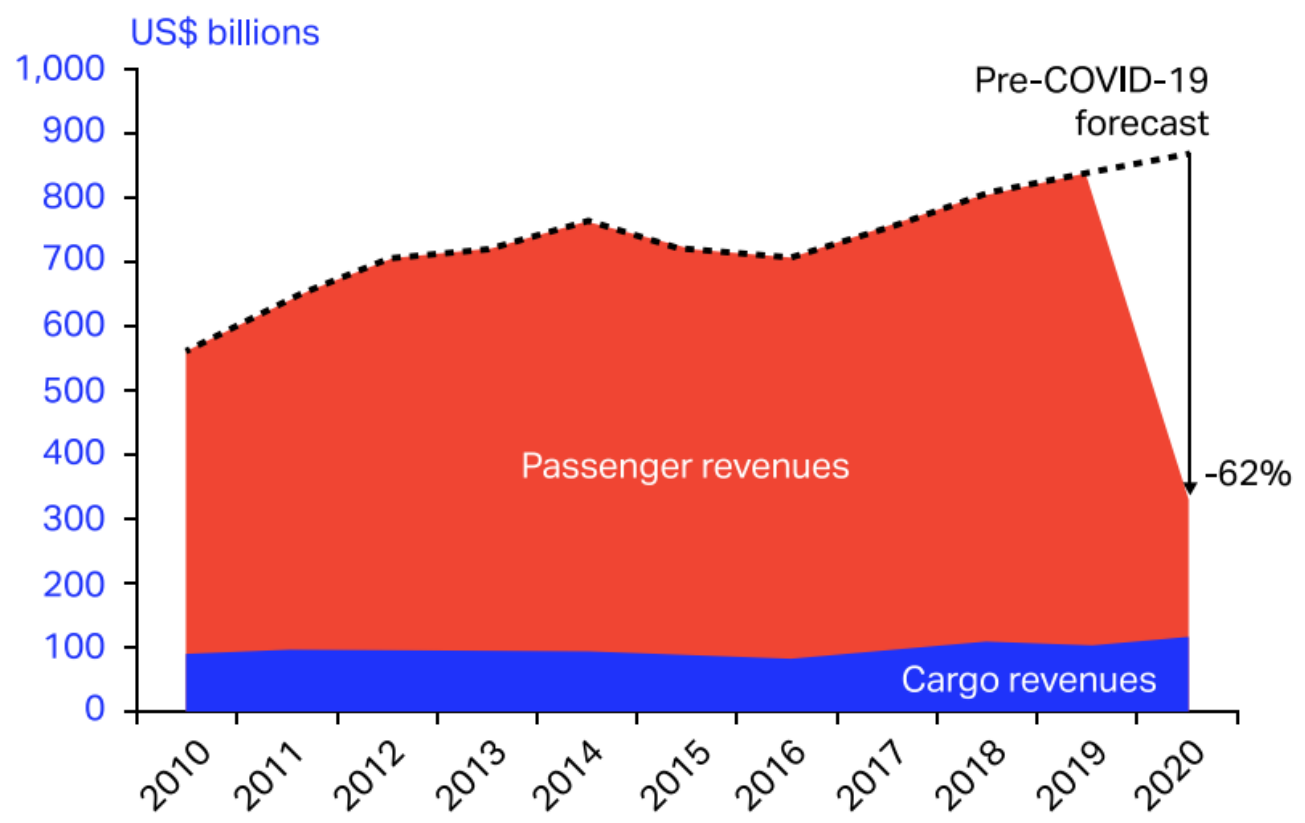

Figure 5. Estimated values of operating income (passenger and freight traffic) Source: IATA (2020, November 25)

In the early days of the crisis, air travel played a crucial role in delivering personal protective equipment and medicines to destinations around the world. Its positive impact continues as 
long as global isolation continues. 46 thousand special flights transported 1.5 million tons of cargo. But the number of cargo planes was insufficient to compensate for the reduction in cargo traffic in passenger aircraft by $40-45 \%$. Therefore, passenger planes were converted into cargo flights. For example, KLM Cargo and Virgin Atlantic aircraft carry cargo in the passenger seats in the cabin, and in the cabins of Swiss WorldCargo and Finnair cargoes are installed in the place of dismantled passenger seats.

To help with this, IATA has published recommendations for removing regulatory barriers. For example, cargo can be transported on seats without the permission of the civil aviation authorities. If the airline decides to remove the passenger seats, it needs more permits. And, of course, it was necessary to consider and approve the transportation of dangerous goods in the passenger compartment and weight restrictions.

However, the use of a passenger cabin for carrying goods is of great importance to the amount of cargo transported. There were and still are many problems facing air freight. IATA is constantly working with ICAO to encourage governments around the world to take the necessary steps to support global logistics. For the most part, governments have responded positively, but operational difficulties persist.

For example, airports, especially alternative airports used in emergencies, must be kept in working order. However, many of these secondary facilities ceased to operate due to the pandemic and were therefore effectively closed.

Meanwhile, the main centers remain open, but at existing intervals and curfews they need to be changed or abolished to allow freight flights. And since most cargo flights are charter, permits must be issued in an expedited manner. Rules for the crew are another regulatory hurdle. It is clear that crews cannot comply with the 14-day quarantine. Exceptions are therefore needed so that crew members can return home to their families, taking into account all possible security measures.

The COVID-19 crisis has led to atypical problems for the air cargo industry, especially in light of government restrictions on health and safety. Problems include delays in obtaining charter permits, and no exceptions for COVID-19 testing for air cargo crews.

In response, IATA calls on governments to:

- reduce the time of registering charter operations;

- exempt cargo crews from quarantine rules that apply to the general population;

- provide appropriate personnel and equipment for efficient cargo handling;

- recognize mutually agreed global standards, such as health certificates and licenses;

- make alternative airports available even in the absence of passenger traffic.

Cargo flights of passenger planes are cost-effective, apparently due to high transportation tariffs and low fuel prices, which can change at any time. Removing passenger seats is a timeconsuming technical procedure, which increases the costs of airlines; and loading and unloading in the cabin is a grueling and difficult task, which increases the time spent on loading 
and unloading. In addition, cargo in such aircraft is moved through the passenger door, which makes their use impractical for the transportation of large equipment.

The Ukrainian air transportation market also showed a significant decline in activity. For three quarters of 2020, airlines carried 3,770.8 thousand passengers, i.e., compared to the same period in 2019, this figure decreased by $64.6 \%$. Performed passenger-kilometers for three quarters of 2020 amounted to 7.9 billion passenger-km, with a decrease compared to the same period in 2019 by $65.9 \%$ (see Table 1 ).

Table 1. Ukrainian airlines performance indicators for 2019-2020

\begin{tabular}{lcc}
\hline \multicolumn{1}{c}{ Indicators } & 30 2019 & $3 Q 2020$ \\
\hline & \multicolumn{2}{c}{ Total } \\
\hline Passengers transported, thousand people & 10664,5 & 3770,8 \\
\hline including on regular lines, thousand people & 6508,2 & 1509,3 \\
\hline Executed passenger-kilometers, billion passenger-km & 23,2 & 7,9 \\
\hline including on regular lines, billion passenger-km & 13,8 & 2,7 \\
\hline Cargo and mail transported, thousand tons & 68,4 & 62,0 \\
\hline including on regular lines, thousand tons & 15,0 & 4,2 \\
\hline Executed ton-kilometers (cargo + mail), million ton- & 222,8 & 217,6 \\
kilometers & 72,6 & 15,2 \\
\hline including on regular lines, million ton-kilometers & 79,7 & 34,2 \\
\hline Executed commercial flights, thousand & 52,0 & 15,6 \\
\hline including on regular lines, thousand & Including international \\
\hline & 9781,0 & 3380,6 \\
\hline Passengers transported, thousand people & 5632,6 & 1124,4 \\
\hline including on regular lines, thousand people & 22,8 & 7,7 \\
\hline Executed passenger-kilometers, billion passenger-km & 13,4 & 2,5 \\
\hline including on regular lines, billion passenger-km & 68,1 & 61,8 \\
\hline Cargo and mail transported, thousand tons & 14,9 & 4,1 \\
\hline including on regular lines, thousand tons & 222,6 & 217,5 \\
\hline Executed ton-kilometers (cargo + mail), million ton- & 72,5 & 15,1 \\
\hline kilometers & 67,0 & 27,2 \\
\hline including on regular lines, million ton-kilometers & 40,6 & 9,6 \\
\hline Executed commercial flights, thousand & & \\
\hline including on regular lines, thousand & & \\
\hline Source: Ministry of Transport and Communications of Ukraine. (2020). The results of the aviation industry of \\
Ukraine for 9 months of 2020. & & \\
& & \\
\hline
\end{tabular}

During three quarters of 2020, 26 domestic airlines operated flights on the passenger and freight transportation market, and according to statistics, 34.2 thousand commercial flights were performed (for the same period in 2019 they accounted for 79.7 thousand).

It should be noted that the volume of freight and mail for 9 months of 2020 decreased by only 9.4\% compared to the previous year and amounted to 62 thousand tons (68.4 thousand tons in 2019). Cargo and mail were transported by 19 Ukrainian airlines, with the largest share of 
transportation (92\%) performed by ZetAvia, ATP Antonov, Ukraine International Airlines, Maximus Airlines, Constanta and SkyUp. It should also be noted that most air cargo is charter flights to other countries.

Comparing the statistics of cargo and postal traffic, it can be concluded that the airports of Ukraine handle about $60 \%$ of cargo and mail transported by airlines of Ukraine (see Figure 6).

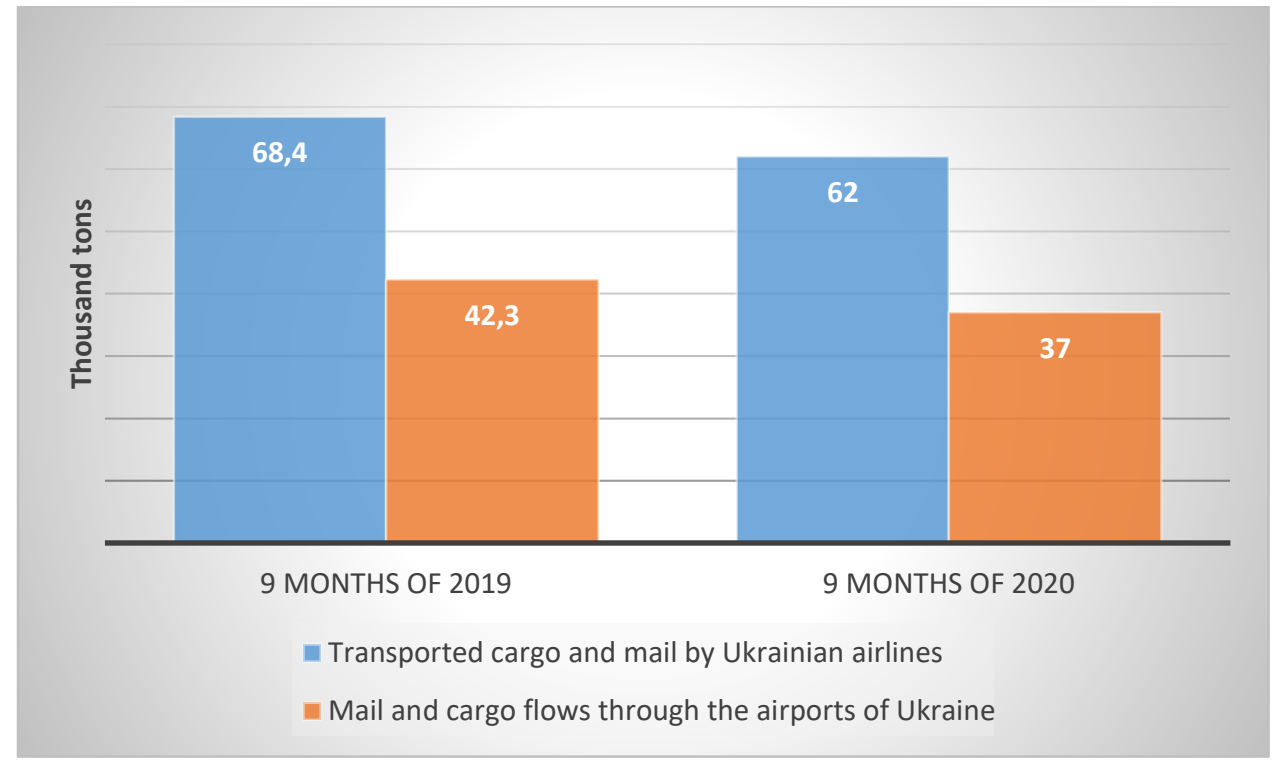

Figure 6. Volumes of cargo and mail transported by Ukrainian airlines and cargo and mail flows through Ukrainian airports for 9 months of 2019 and 2020

Source: developed by the author based on Ministry of Transport and Communications of Ukraine (2020)

The system-structural analysis and the method of logical generalization allowed determining the structure and relations among transport systems in a united information space; system approach, decomposition method and functional analysis have defined the mechanism of information interaction of enterprises on the basis of digital platform, the use of digital technologies, namely digital platforms. The set of selected methods provides dialectical unity, the possibility of generalization, prediction and explanation of information exchange processes in supply chains involving air transport.

The study is informed by legislation and other regulations on the functioning and development of the air transportation market, statistics of ICAO, IATA and the State Statistics Service of Ukraine, standards of information exchange in supply chains, the Internet resources, domestic and foreign periodicals, as well as the author's own research.

\section{Results and Discussion}

Against the background of a significant reduction in passenger air traffic, freight traffic can be an important factor in the resumption of scheduled air services, as for many airlines freight 
traffic is insignificant and complementary. Freight development strategies can give airlines a way out of the crisis, as forecasts of passenger traffic resumption are uncertain and freight traffic is likely to increase.

Strategies to increase air freight should be developed in the context of digital transformations. The global aviation crisis caused by the COVID-19 virus has only exacerbated the need for digital technology, as many activities have moved online. The main trends can be observed at the moment, which further emphasizes the impact of digital optimization Diggin Travel (2019).

1. Focusing on reducing costs and finding fast sources of income accentuates the importance of optimizing conversions (meaning online conversions directly before booking). During each crisis, airlines do two things: aggressively reduce costs and look for sources of rapid revenue growth. Conversion optimization affects both cost and profit. More conversions mean more orders and more revenue.

2. The key is consumer understanding, the same approach to all will no longer work in the future. Over time, consumers will start thinking about travel again and will make travel reservations, but they will have far more fears than ever. They will also need more information on hygiene measures, restrictions and recommendations. Such fears will be different in origin (country of departure, airports) and especially in the destination (country, region) where they are sent. Optimizing the activities of airlines will be the ability to understand such concerns of each of the passengers, at least key segments and to develop individual ways to book travel. A 2019 study by Digital Airlines Retail found that $64 \%$ of airlines have the same booking path for all consumers. Figure 7 presents the main factors that affect the passengers' sense of safety during flights.

3. Contactlessness is an opportunity for innovation and automation. One of the changes in passenger behavior is that people are looking for less physical contact. Automation processes in the aviation industry have always taken place, but now companies are looking for opportunities for even greater digitalization: building direct booking channels, increasing the involvement of mobile applications, increasing the use of registration on the Internet and more.

4. Planning for future growth. Today, airlines are actively looking for ways to reduce costs and this is also reflected in the reduction in the employees' number, including experts in digital technology. Therefore, airlines need to have a clear vision of organizing current operations, bearing in mind that resources will be needed again when the situation improves.

5. The emergence of new groups of Internet users. Currently, even those people who used the Internet in pre-crisis times are at least increasing their online presence. Not only will there be more people booking online, there will be more people getting used to the new digital experience (ordering food for delivery, other retail, etc.). This is an opportunity for airlines to innovate and test new concepts, such as pre-ordering and ordering food at airports or retail on board. 
Seeing sanitization being performed throughout the airplane

Seeing sanitization being performed throughout the airport

Having hand sanitizer readily available on board

Screening of all passengers for coronavirus/COVID-19 at departure

Receiving a personal sanitization kit to clean your seat area

Social distancing on aircraft

Temperature testing of all passengers at departure

Mandatory wearing of masks in airports, planes and by the crew

Receiving a mask at check-in

A coronavirus/COVID-19 immunity certification guaranteeing you exemption from quarantine in any country

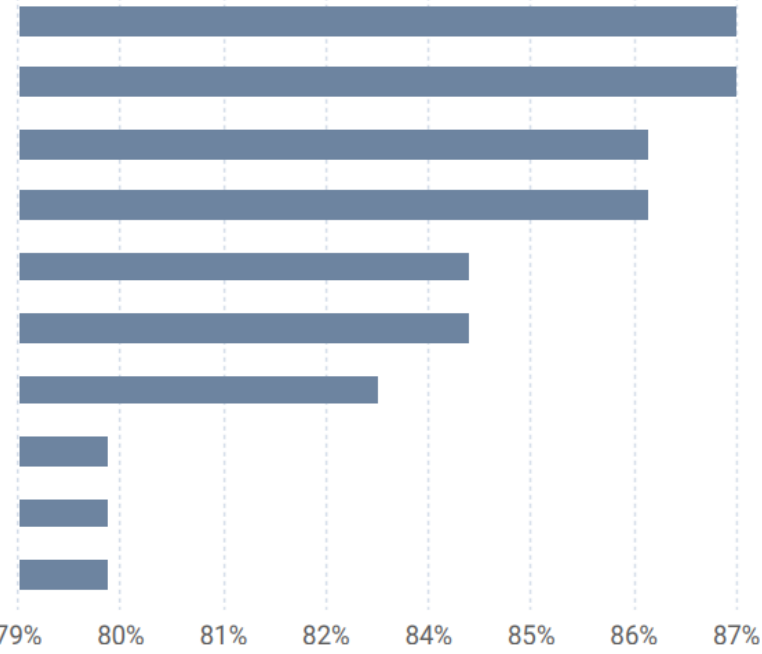

Figure 7. Factors that make passengers feel safer in flight Source: Diggin Travel (2020)

Undoubtedly, air transport plays an extremely important role in servicing global supply chains, as it offers highly integrated and comprehensive fast delivery with safe, reliable, convenient and highly efficient services.

Analysis of trends in the logistics services market and global supply chains shows an increase in competition among the modes of transport, the main feature of which is not the volume of traffic, but the services provided and the total added value for end users, an integral part of which is the speed of response to customer inquiries. Against this background, the interaction among the modes of transport is critical.

Airports are important multimodal operators and central hubs of global supply networks (Allroggen \& Malina, 2014, Reis et al., 2013). Generalization of different opinions of researchers, in particular, Vega (2008), Feng et al., (2015), Kuljanin et al. (2015), allows identifying the following benefits of using air transport in global chains of trade:

- expanding access to major markets and ensuring the internationalization of producing spare parts, components and finished products;

- increasing productivity and efficiency of supply chains by reducing the delivery time and timeliness of delivery, which allows reducing inventories significantly;

- ability to move goods quickly and reliably across borders, reducing the risk of losing goods during air transportation, the probability of cargo damage is minimized. Increased reliability is also provided by a system of continuous monitoring, which allows checking the location and condition of the cargo, regardless of its current location;

- stimulating innovation, as air transport promotes effective cooperation of companies from different countries and uses the latest information and communication technologies;

- better use of economies of scale through efficient airline networks and consolidation of global and regional freight flows; 
- better mobility and efficiency of contacts among sellers, buyers and consumers, which contributes to the growth of the level of logistics service.

However, in the field of freight transport, involving air transport, there are many significant problems that create barriers to its effective use:

1. The complexity and duration of customs procedures in registering export-import trade flows related to the specifics of goods and cargo. It takes into account various factors, such as weight, dimensions and specifications of the cargo, customs relations between the buyer country and the seller country, and so on.

2. The presence of various factors influencing the organization of logistics schemes for the movement of goods, the correct calculation of the delivery route, cost optimization and prevention of possible risks.

3. High cost of air transportation, due to the high costs of air carriers for the maintenance and operation of aircraft, as well as high airport fees for maintenance and support. The calculation of the cost of services in the carriage of goods has an interesting feature. On the one hand, the more cargo on board, the greater the profit; on the other hand, the aircraft has a capacity limit, so the cost of air cargo is calculated as the ratio of weight to a certain volume (Li et al., 2012). It consists of several components: the cost of transportation (air freight); cost of allowances (fuel, airport, security); the cost of cargo handling at airports (loading, unloading, paperwork). It should also be noted that deregulation of air traffic has increased freight rates, but has given shippers more choice among carriers in terms of fares, consequential damages and overcharged charges (Chao \& Hsu, 2014).

4. The structure of the airline network, as air transport is inextricably linked with the airport system. Since air transportation services are provided by airlines, for optimal operation, these services need to be adjusted and fine-tuned in accordance with the logistics requirements, simply put - to get into the popular "air flows". Freight airlines continuously monitor the current situation in major consumer markets, because it directly affects the fluctuations of freight flows - sources of income in the business of freight carriers. Fall in regular cargo flows between major consumer markets - one of the main prerequisites for stable operation of the airline (Derigs et al., 2009).

According to some experts, due to the globalization of trade and economic activity, the growth rate of air cargo will grow faster than passenger (Kiso \& Deljanin, 2009). They also emphasize that the physical movement of goods has become an extremely complex operation involving the use of new technologies for the movement, storage and tracking of goods (Derigs et al., 2009, Becker \& Nadja, 2007).

This process involves a variety of players, the general structure of which and the relations among them are presented in Figure 8. 


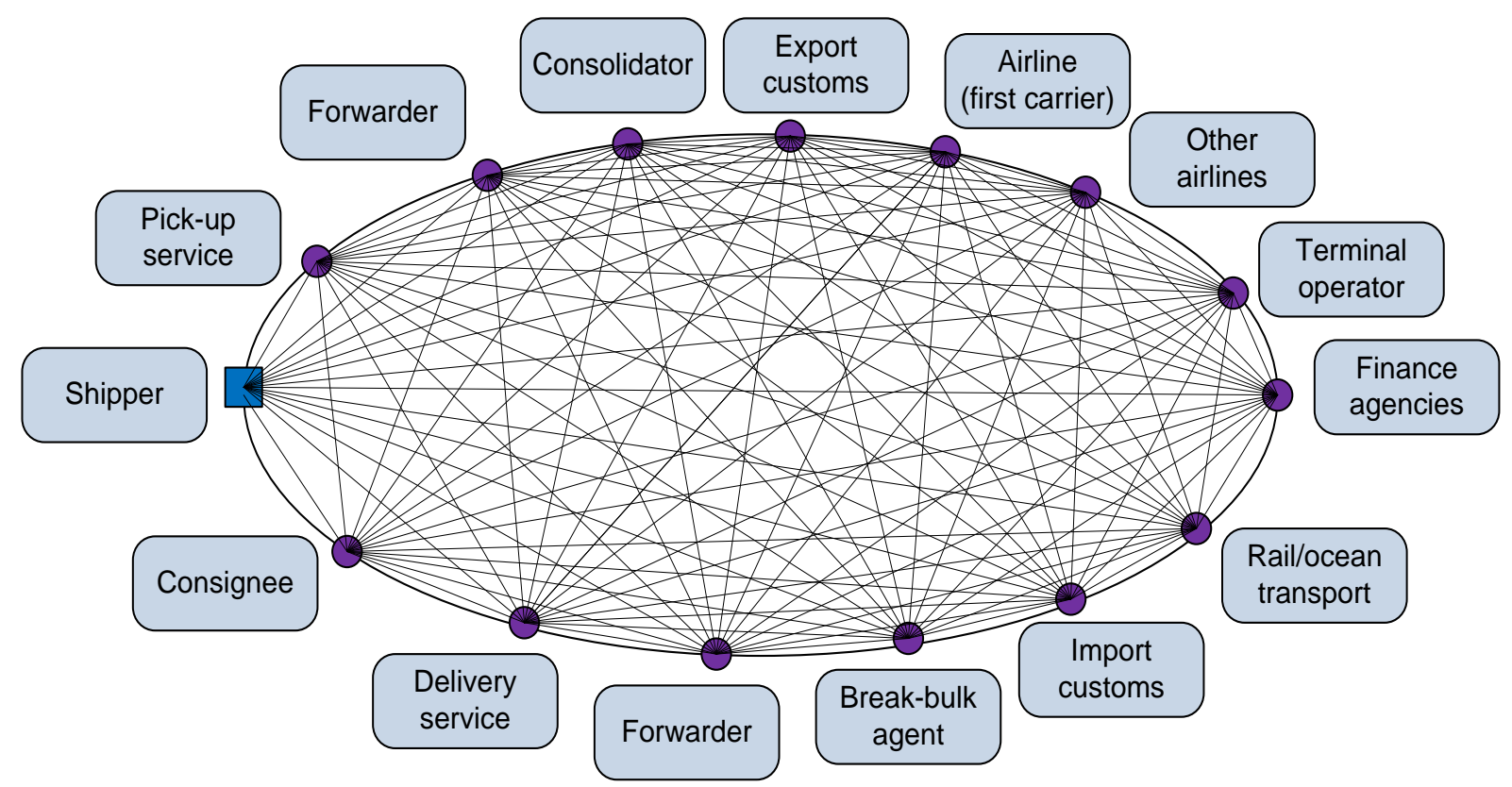

Figure 8. Air cargo industry participants and their links

Source: developed by the author.

Cargo supply chain is a set of interconnected participants, settlements, information exchange procedures that ensure goods' transportation from the point of departure to the destination. All participants in this process have a shared responsibility to ensure that air cargo moves safely and securely throughout the chain. The initiators of the process of moving air cargo are the seller (or "shipper") and the buyer (in the context of international trade called "importer"), who want to exchange goods by air.

From a commercial point of view, the shipper is located at the opposite point from the buyer (or "importer" in international trade) in the supply chain. The person initiating the supply of goods may be their manufacturer or buyer for resale. The consignor (in the international context "importer") acts in accordance with established procedures and participates in the process of exchanging information received in connection with the purchase and sale of goods. Often the shipper uses the services of a broker or agent who deals with organizational and regulatory aspects of its commercial activities, including preparing product declarations for customs, resolving issues related to numerous potential licenses, permits and certificates that may be required by other regulatory authorities. That is, the freight forwarder is an intermediary between the shipper and the airline. The airline receives, stores, transmits, tracks, loads and unloads cargo, as well as assigns and manages capacity. A detailed description of operations and responsibilities of key participants in the cargo aviation chain is summarized in the work by Feng et al. (2015).

It should be noted that the movement of goods in the air takes only $17 \%$ of the time. Ground handling operations to the airport account for an average of about $26 \%$ of the total delivery time, and the remaining $57 \%$ of the transport time is required for delivery from the airport to the consignee (Scholz, 2011). It is possible to reduce the total duration of cargo delivery with 
the participation of air transport by integrating and synchronizing processes in the chains of freight traffic.

Transportation of goods by air is often part of the supply chain, the digital transformation of which will optimize the activities of each of its links. The main goal of digital transformation should be to organize the interaction of all participants in the supply chain and not least the various transport systems.

The complex interaction of different types of transport systems allows providing high quality of service and full satisfaction of the need for transportation by volume, directions and nomenclature of goods. In this case, as a result of the interaction among different types of transport systems, there are produced finished products in accordance with the specified criteria, the rational use of vehicles, energy resources and money with minimal costs for production, transportation and consumption of goods transported. (Kryizhanovskiy \& Shashkin, 1998). The object of transportation acquires consumer value when delivery covers the entire path "door to door" from the sphere of production to the sphere of its consumption. This can be done through the integrated interaction among different types of transport systems, creating a single transport system that provides global supply chains.

The effectiveness of production management in a single transport system depends on the state and development of vehicles, communications, transport management systems, technologies to ensure the readiness of the subsystems of the transportation process, productive use of material and financial resources, and production and management staff, conditions of transport systems' interaction, marketing, management and logistics of transport enterprises, systems supporting the vital activity of transport enterprises, information and telecommunication system with information and logistics centers which provide analytical support at performing mixed transportations. The scheme of a single transport system that provides global supply chains is shown in Figure 9.

A united information space should ensure the compatibility of information systems of producers and consumers of transport products at all stages of the product life cycle "from raw material extraction to production and sale of specific products." A united information space is able to ensure the rapid exchange of information between the interacting transport hubs and the bodies that ensure the movement of vehicles, including the exchange of information on the management of production and commercial activities of transport enterprises.

The united information space is substantiated and formed in accordance with the production and management structure of the unified transport system and ensures its effective functioning and development.

To make a decision, each of the participants in the transportation process needs information about the state of the commodity and transport markets, producers and consumers of goods, the availability of transport companies, the composition and condition of their vehicles; data 
on goods and routes of their delivery, on transport hubs and conditions of cargo processing in them. The information must be complete, timely, reliable, and compatible for all modes of transport. Special conditions must be provided for collecting, processing, storing, analyzing, and using information for decision-making.

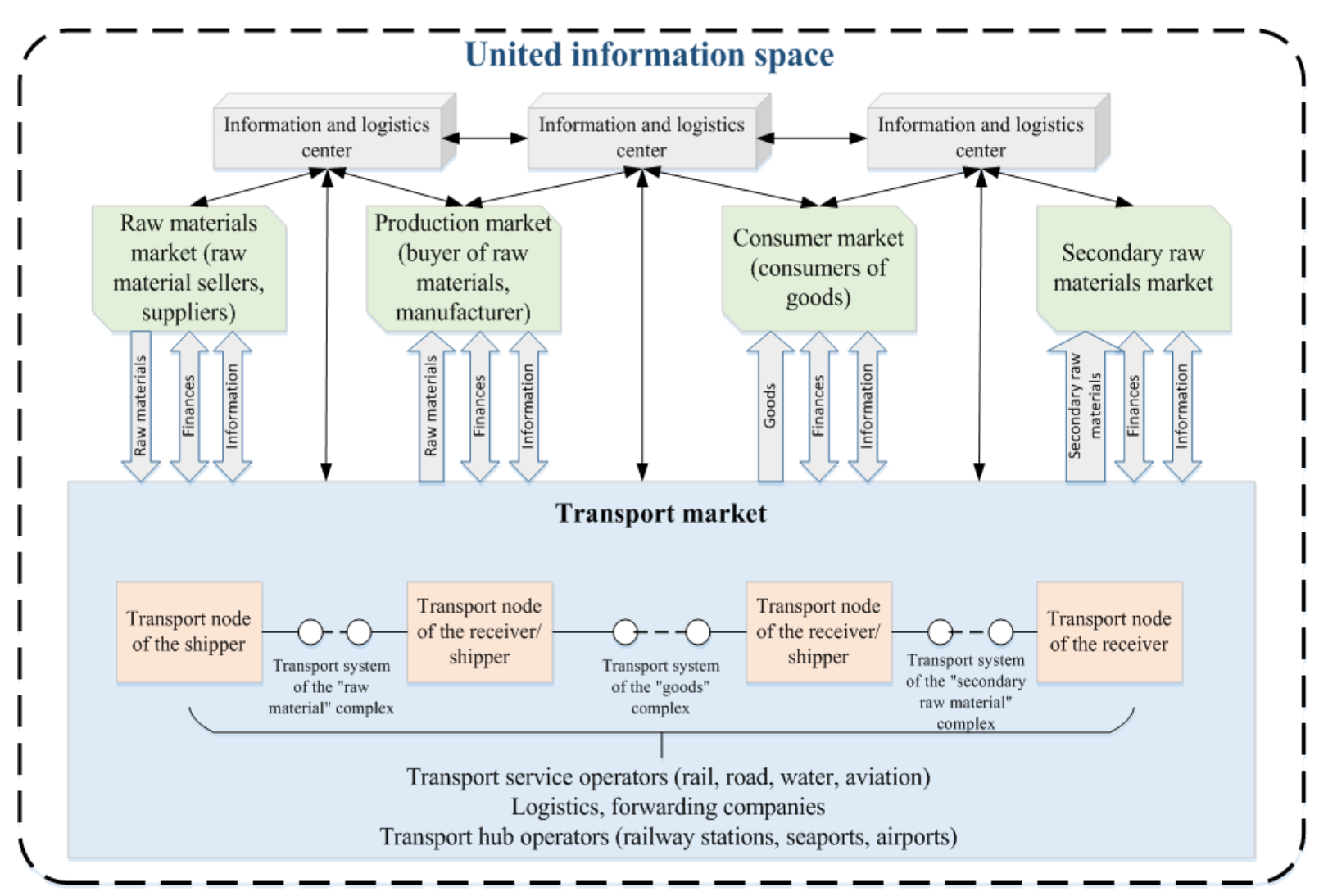

Figure 9. A single transport system that provides global supply chains Source: developed by the author.

The scheme of information interaction between supply chain participants including air transport based on the digital platform in the context of a united information space is shown in Figure 10.

It is important to note that digital platforms are not just technologies, they are a business model that creates value by bringing consumers and producers together (Moazed, 2018). Traditional companies are often called linear, because their activities are well described by a typical linear supply chain. Line companies create value in the form of goods or services and then sell them to the consumer (Johnson, 2018). The platform is focused exclusively on building and promoting the network. Platforms do not have means of production - instead they create means of communication. 


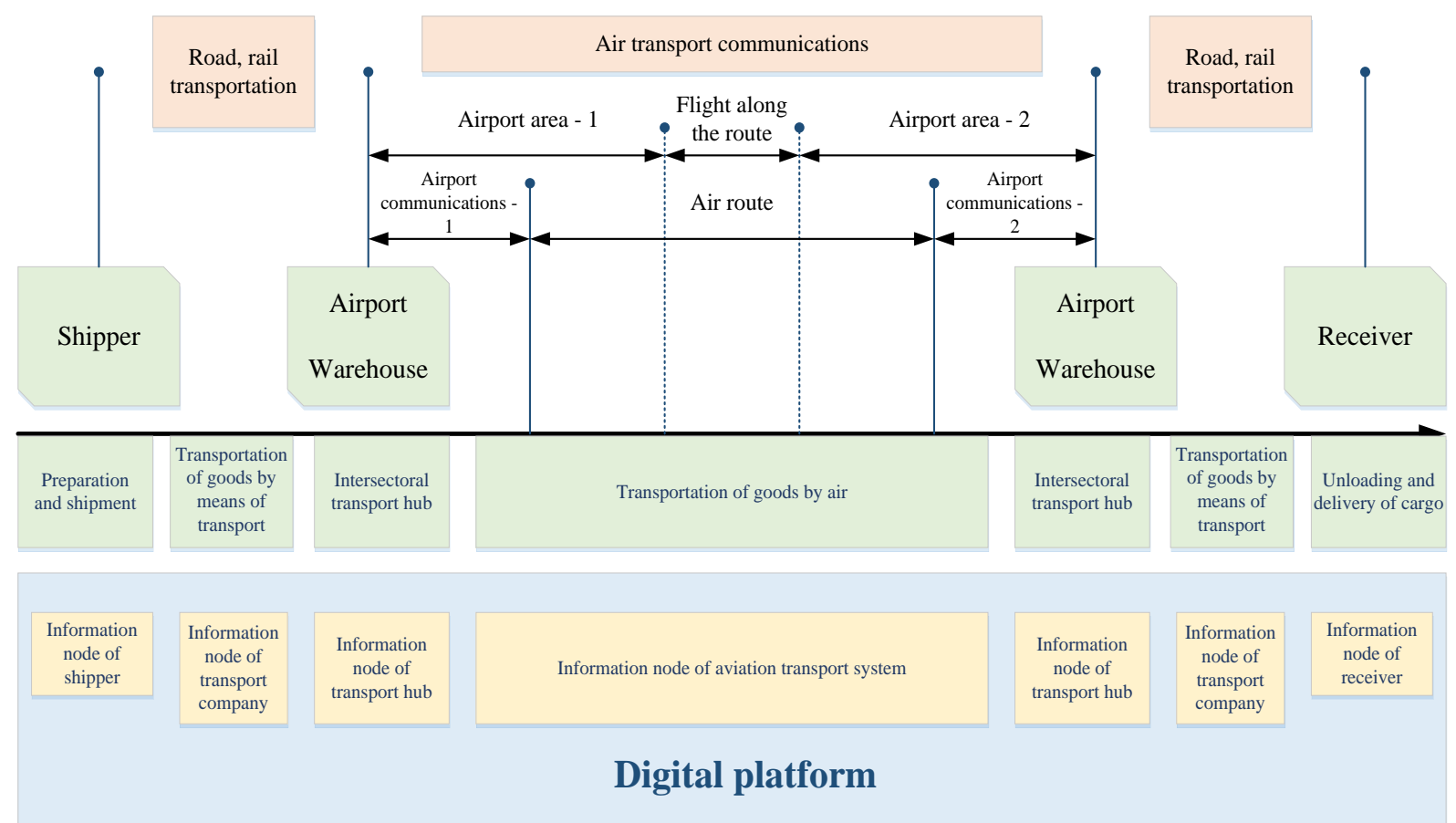

Figure 10. The scheme of information interaction among supply chain participants including air transport based on the digital platform

Source: developed by the author.

Digital platforms play a key role in developing e-commerce and one of their most important characteristics is the flow of data from users, which can be further analyzed, used and monetized. Data has become a valuable resource that can be obtained in the digital economy (United Nations Conference on Trade and Development (2019).

\section{Conclusions}

Based on a thorough analysis of the dynamics of global and national markets and air traffic in a global pandemic, the need to improve the processes of information exchange among enterprises to reduce operating costs and speed up cargo delivery time was justified. Revenues of the aviation industry in 2020 amounted to only $43.6 \%$ of the corresponding figure for 2019 and there was the largest decrease in passenger traffic. The volume of air cargo decreased by a quarter, but the situation was not as critical as in the field of passenger air transport. In Ukraine, the volume of transported passengers for 9 months of 2020 decreased by $64.6 \%$ compared to the same period in 2019 , while the volume of freight traffic decreased by only $9.4 \%$ compared to last year. Due to quarantine restrictions, the number of procedures and documents for transportation registration has increased, which very clearly emphasized the need for high-quality, efficient, clear and complete information exchange amongst enterprises, as well as between enterprises and government agencies. It is concluded that the current crisis shocks associated with the spread of coronavirus may be a catalyst for change that will allow aviation market players in the future to optimize their activities and reorganize business processes in supply chains. 
As a result of the conducted research the theoretical and methodical provisions of the aviation enterprises interaction organization based on the digital platform were defined. The complex interaction of the supply chains participants including air transport allows providing high quality of service and full satisfaction of the need for transportation by volume, directions and nomenclature of cargoes.

Emphasis is placed on the fact that the active introduction of digital technologies in the activities of aviation enterprises creates the preconditions for forming a united information space that provides effective interaction of transport systems of different levels. A united information space is able to ensure the operational information exchange between the interacting transport hubs and the bodies that ensure the movement of vehicles, including the exchange of information on the management of production and commercial activities of transport enterprises. Today, digital platforms are not just a technology that creates value by providing direct interaction between two or more groups of participants, but also a business model.

Accordingly, airlines need to review existing market strategies and develop new business models in the context of digitalization. The mechanism of information interaction of supply chain participants including air transport enterprises based on the digital platform is proposed, which will allow synchronizing demand for air transportation and supply online, coordinating business processes and operations related to cargo delivery on a door-to-door basis with the participation of different modes of transport, as well as creating added consumer value and improving the quality of customer service. The proposed mechanism can be implemented with the assistance of Ukraine's leading aviation companies in cooperation with public authorities, as well as logistics operators who are direct participants in the supply chain.

\section{References}

Allroggen, F., \& Malina, R. (2014). Do the Regional Growth Effects of Air Transport Differ Among Airports? Journal of Air Transportation Management, 37(1), 1-4. https://doi.org/10.1016/j.jairtraman.2013.11.007.

Becker, B., \& Nadja, D. (2007). Managing the Complexity of Air Cargo Revenue Management. Journal of Revenue and Pricing Management, 6(3), 175-187. https://doi.org/10.1057/palgrave.rpm.5160084.

Chao, C.-C., \& Hsu, C.-W. (2014). Cost Analysis of Air Cargo Transport and Effects of Fluctuations in Fuel Price. Journal of Air Transport Management, 35, 51-56. https://doi.org/10.1016/j.jairtraman.2013.11.010.

Chen, Y., Pereira, I., \& Patel, P. (2020). Decentralized Governance of Digital Platforms. Journal of Management, Forthcoming. https://doi.org/10.1177/0149206320916755.

Dalinger, Y. (2017). Organizaciya informacionnogo vzaimodejstviya proizvodstvennyh processov aeroporta [Organization of Information Interaction of Airport's Production Processes]. Civil 
Aviation High Technologies Nauchnyi Vestnik MGTU GA, 20(1), 116-122. Retrieved from https://avia.mstuca.ru/jour/article/download/1038/917 [in Russian].

Derigs, U., Frederichs, S., Schafer, S. (2009). A New Approach for Air Cargo Network Planning. Transportation Science, 43(3), 370-380. https://doi.org/10.1287/trsc.1090.0282.

Diggin Travel. (2019). 2019 Airline Digital Retailing Survey. Diggin Travel. Retrieved from https://diggintravel.com/2019-airline-industry-trends/.

Diggin Travel. (2020). 2020 Airline Digital Optimization Yearbook. Diggin Travel. Retrieved from https://www.diggintravel.com/2020_Airline_Digital_Optimization_Yearbook.pdf.

Dmitriev, A., Plastunyak, I. (2019, 10-11 October). Platformennaya koncepciya razvitiya cifrovogo transportno-logisticheskih uslug [A Platform Concept for the Development of Digital Transport and Logistics Services]. International Conference "Digital Technologies in Logistics and Infrastructure", St. Petersburg. Politechpress. Retrieved from https://elib.spbstu.ru/dl/2/i2053.pdf/download/i20-53.pdf [in Russian].

Evans, P.C., \& Gawer, A. (2016). The Rise of the Platform Enterprise. A Global Survey. The Center for Global Enterprise. Retrieved from https://www.thecge.net/app/ uploads/2016/01/PDF-WEBPlatform-Survey_01_12.pdf

Feng, B., Li, Y., \& Shen, Z. J. M. (2015). Air Cargo Operations: Literature Review and Comparison with Practices. Transportation Research, Part C: Emerging Technologies, 56, 263-280. https://doi.org/10.1016/j.trc.2015.03.028.

Hagiu, A. (2014) Strategic Decisions for Multisided Platforms. MIT Sloan Management Review, 55(2), 71-80.

International Air Transport Association (IATA). (2020, November 24). Deep Losses Continue Into 2021. International Air Transport Association. Retrieved from https://www.iata.org/en/pressroom/pr/2020-11-24-01/

International Air Transport Association. (2020, November 25). Air Connectivity: Measuring Connections That Drive Economic Growth. International Air Transport Association. Retrieved from https://www.iata.org/en/iata-repository/publications/economic-reports/air-connectivitymeasuring-the-connections-that-drive-economic-growth/.

Johnson, N.L. (2018). Platform vs. Linear: Business Models 101. APPLICO. Retrieved from https://www.applicoinc.com/blog/platform-vs-linear-business-models-101/.

Kiso, F., \& Deljanin, A. (2009). Air Freight and Logistics Services. Promet - Traffic\&Transportation, 21 (4), 291-298. https://doi.org/10.7307/ptt.v21i4.243.

Kryizhanovskiy, H., \& Shashkin, V. (1998). Upravlenie transportnymi sistemami [Transport Systems Management]. St. Petersburg: «Sevtrasinvest» [in Russian].

Kuljanin, J., Kalic, M., \& Dožić, S. (2015). An Overview of European Air Cargo Transport: The Key Drivers and Limitations. Second Logistical International Conference, Belgrade, Serbia.

Li, Z., Bookbinder, J.H., \& Elhedhli, S. (2012). Optimal Shipment Decisions for an Airfreight Forwarder: Formulation and Solution Methods. Transportation Research, Part C: Emerging Technologies, 21, 17-30. https://doi.org/10.1016/j.trc.2011.08.001. 
Marintseva, K. (2013). Tekhnologiya standartu IATA E-FREIGHT [IATA E-FREIGHT Standard Technology]. Journal of Dnipro National University of Railway Transport named after Academician V. Lazaryan, 5, 45-50. https://doi.org/10.15802/tstt2013/19277 [in Ukrainian].

Marusin, A., \& Ablyazov, T. (2019). Osobennosti cifrovoj transformacii transportno-logisticheskoj sfery [Features of the Digital Transformation of the Transport and Logistics Sector]. Economics: Yesterday, Today and Tomorrow, 9(3A), 71-78. https://doi.org/10.34670/AR.2019.89.3.007 [in Russian].

Ministry of Transport and Communications of Ukraine. (2020, October). Pidsumky diialnosti aviatsiinoi haluzi Ukrainy za 9 misiatsiv 2020 roku [The results of the aviation industry of Ukraine for 9 months of 2020]. Kyiv: Ministry of Transport and Communications of Ukraine. Retrieved from https://www.google.com/url?sa=t\&rct=j\&q=\&esrc=s\&source=web\&cd=\&cad=rja\&uact=8\&ved=2 ahUKEwiW6_3Trc3uAhWqxoUKHX6FAp4QFjABegQIAxAC\&url=https\%3A\%2F\%2Favia.gov.ua\%2F wp-content\%2Fuploads\%2F2020\%2F10\%2FPidsumki-roboti$9 \mathrm{mis} 2020$. doc\&usg=AOvVaw1fwFDjxWDZfOFXU5jKoOZo.

Moazed, A. (2018). Platform Business Model - Definition. APPLICO. Retrieved from https://www.applicoinc.com/blog/what-is-a-platform-business-model/

Molchanova, K. (2014). Aspekty vprovadzhennia tekhnolohii e-freight [Aspects of E-Freight Technology Implementation]. Journal of Lviv Polytechnic National University, 811, 241-246. Retrieved from http://ena.Ip.edu.ua:8080/handle/ntb/29398 [in Ukrainian].

Reis, V., Meier, F., Pace, G., \& Palacin, R. (2013). Rail and Multi-Modal Transport. Research in Transportation Economics, 41 (1), 17-30.

Reuver de, M., Sørensen, C., \& Basole, R.C. (2018). The Digital Platform: A Research Agenda. Journal of Information Technology, 33(2), 124-135. https://doi.org/10.1057/s41265-016-0033-3.

Ryzhkova, M. (2019). Konceptualizaciya fenomena "cifrovaya platforma": rynok ili biznes?

[Conceptualizing the Digital Platform Phenomenon: Market or Business?]. Tomsk State University Journal of Economics, 47, 48-66. https://doi.org/10.17223/19988648/47/4 [in Russian].

Scholz, A. B. (2011). Network Structures of Cargo Airlines - An Empirical and a Modelling Approach. Karlsruhe: KIT Scientific Publishing.

Sutherland, W., \& Jarrahi, M.H. (2018). The Sharing Economy and Digital Platforms: A Review and Research Agenda. International Journal of Information Management, 43, 328-341. https://doi.org/10.1016/j.jijinfomgt.2018.07.004.

Tauscher, K., \& Laudien, S. (2018). Understanding Platform Business Models: A Mixed Methods Study of Marketplaces. European Management Journal, 36, 319-329. https://doi.org/10.1016/j.emj.2017.06.005.

United Nations Conference on Trade and Development. (2019, March). Making Digital Platforms Work for Development. Geneva: United Nations Conference on Trade and Development. Retrieved from https://unctad.org/system/files/official-document/presspb2019d2_en.pdf.

Vega, H. (2008). Air Cargo, Trade and Transportation Costs of Perishables and Exotics from South America. Journal of Air Transport Management, 14 (6), 324--328. https://doi.org/10.1016/j.jairtraman.2008.08.006. 
Zatsarinnyy, A., \& Shabanov, A. (2019). Model of a Prospective Digital Platform to Consolidate the Resources of Economic Activity in the Digital Economy. Procedia Computer Science, 150, 552-557. https://doi.org/10.1016/j.procs.2019.02.092. 